\title{
STRATEGI PENGEMBANGAN BAWANG MERAH DI KOTA PEKANBARU
}

\section{Shallots Development Strategy in Pekanbaru City}

\author{
Afrizal, Syaiful Hadi, Evy Maharani \\ Program Studi Magister Agribisnis Universitas Riau \\ Kampus Bina Widya Simpang Baru-Pekanbaru \\ [Diterima: Juli 2018; Disetujui: Agustus 2018]
}

\begin{abstract}
One of the efforts to reduce dependence on imported shallots is by improving the production of shallots. The purpose of this research is to making formulate a strategy for developing lowland shallots agribusiness in the city of Pekanbaru. The research is held in 2018 with responded to the farmer of shallots as many as 24 people and 3 field extension officers. The analysis A'SWOT is the combination of SWOT and AHP is used to formulate the strategy for developing shallots in the city of Pekanbaru. The results show that the average of net income to the farmer's bima Brebes varieties with a land area of 0,5 ha is Rp. 47.187.000. The RCR value of shallot farming is 1,50 which means that the Brebes variety of shallot farming in Pekanbaru City is economically profitable to it can continue. The result of the analysis of A'WOT shows that 10 strategies can be implemented in the development of shallots agribusiness in Pekanbaru with priority strategy development of shallots agribusiness in the city of Pekanbaru is shallots agribusiness.
\end{abstract}

Keywords: Shallots, agribusiness, SWOT, AHP

\begin{abstract}
ABSTRAK
Salah satu upaya untuk mengurangi ketergantungan terhadap import bawang merah adalah dengan meningkatkan produksi bawang merah.Penelitian ini bertujuan untuk memformulasikan strategi pengembangan agribisnis bawang merah dataran rendah di Kota Pekanbaru. Penelitian ini dilaksanakan pada tahun 2018 dengan responden petani bawang merah sebanyak 24 orang dan 3 orang petugas penyuluhan lapangan. Analisis A'WOT yaitu kombinasi antara SWOT dan AHP digunakan untuk memformulasikan strategi pengembangan agribisnis bawang merah di Kota Pekanbaru.Hasilpenelitian menujukkan bahwa rata-rata pendapatan bersih pada petani bawangmerah varietas bima brebes dengan penguasaan lahan seluas 0,5ha sebesar Rp.47.187.000. Nilai RCR usahatani bawang merah sebesar 1,50 yang bermakna bahwa usahatani bawang merah varietas brebes di Kota Pekanbarusecara ekonomi menguntungkan sehingga dapat terus dilanjutkan. Hasil analisis A'WOT, menunjukkan bahwa terdapat 10 strategiyang dapat dilaksanakan pada pengembanganagribisnis bawang merah di Kota Pekanbaru dengan strategi prioritaspengembangan agribisnis bawang merah di Kota Pekanbaru bawang adalah pelatihan agribisnis bawang merah.
\end{abstract}

Kata kunci : Bawang merah, Agribisnis, SWOT, AHP

\section{PENDAHULUAN}

Bawang merah merupakan komoditas hortikultura jenis sayur-sayuran yang dibutuhkan oleh hampir semua kalangan. Bawang merah pada umumnya digunakan sebagai bumbu masak sehari-hari pada rumah tangga, rumah makan sampai hotel. Meski konsumsi barang merah relatif cukup besar, namun tingkat ketergantungannya dari luar masih sangat tinggi. Nilai impor bawang merah sepanjang periode 2001-2004 secara kumulatif mencapai 48,15 juta US\$ dengan volume 171,81 ribu ton, meningkat menjadi USD 
172,30juta dengan volume 434,34 ribu ton pada periode tahun 2005-2009. Pada periode tahun2010-2013, nilai impor bawang merah meningkat menjadi USD 219,79 juta dengan volume 452,07 ributon. Sehingga dapat diketahui bahwa nilai impor bawang merah paling besar pada periode tahun 2010-2013. Sementara tingkat pertumbuhan impor bawang merah paling tinggi berada pada periode tahun 2005-2009 mencapai 17,06\%.

Disisi lain, produksi bawang merah Indonesia pada tahun 2010-2014 mengalami naik turun. Pada tahun 2010, total produksi bawang merah Indonesia sebesar 1.048.934 ton, menurun menjadi 893,124 ton pada tahun 2011. Pada tahun 2012, produksi bawang merah Indonesia meningkat menjadi 964.221 ton dan kembali meningkat menjadi1.010.773 pada tahun 2013. Pada tahun 2014, produksi barang merah Indonesia kembali meningkat produksinya menjadi 1.227 .838 pada tahun 2014 atau naik sekitar $21.48 \%$ dari tahun 2013 (Ditjen PPHP, 2014). Namun secara keseluruhan, produksi bawang merah Indonesia masih belum mencukupi kebutuhan sehingga perlu upaya-upaya pengembangan produksi bawang merah.

Kota Pekanbaru merupakan salah satu daerah di Provinsi Riau yang dijadikan daerah pengembangan produksi bawang merah. Penanaman bawang merah di Kota Pekanbaru telah dimulai pada tahun 2015 dengan luas 27 hektar yang tersebar di 4 Kecamatan yaitu Kecamatan Rumbai pesisir seluas 4 hektar, Kecamatan Marpoyan Damai seluas 4 hektar dan

Kecamatan Tenayan Raya seluas 19 hektar. Pada tahun 2016 penanaman bawang merah dilaksanakan pada lokasi yang sama dengan luas tanam yang sama juga.Padatahun 2017, penanaman bawang merah penanaman bawang merah dilakukan di Kecamatan Marpoyan Damai seluas 10 hektardan Kecamatan Tampan seluas 5 hektar.

Pada tahun 2015 produksi bawang merah di Kota Pekanbaru hanya sebesar 92 ton dengan produktivitas sebesar 3,4 ton/hektar. Pada tahun 2016, produksi bawang merah menurun menjadi 41,4 ton dengan produktivitas sebesar 2,07 ton/ha. Padatahun 2017, produksi bawang merah Kota Pekanbarusebesar 60,48 ton dengan produktivitas 2,75 ton/hektar. Capaian produktifitas bawang merah Kota Pekanbaru tahun 2014 ini relatif masih rendah bila dibandingkan dengan sentra tanaman bawang di Indonesia pada amsa yang sama seperti Provinsi Jawa Tengah dengan produktifitas bawang merah bisa mencapai 11,23 ton/hektar, Provinsi Bali dengan produktifitas sebesar 11,23 ton/hektar, Jawa Barat dengan produktifitas sebesar 10,38 ton/hektar, Sumatera Barat dengan produktivitas sebesar 10,38 ton/hektar dan Nusa Tenggara Barat dengan produktifitas sebesar 10,20 ton/hektar(Kementerian Pertanian, 2014).

Berdasarkan kondisi tingginya ketergantungan impor bawang merah dan produktifitas bawang merah yang dikembangkan di Kota Pekanbaru yang sangat rendah dipandang perlu untuk dikaji agar pengembangannya terus berlanjut. Penelitian ini bertujuan untuk memformulasikan strategi pengembangan agribisnis bawang merah dataran rendah di Kota Pekanbaru.

\section{METODE PENELITIAN}

\section{Metode Penentuan Data dan Sampel}

Data yang dikumpulkan untuk penelitian ini adalah data primer dan data sekunder. Data primer diperoleh dengan melalukan wawancara secara langsung dengan petani bawang merah dan dengan berbagai pihak yang terkait langsung dengan agribisnis bawang merah di Kota Pekanbaru diantaranya Dinas Pertanian Kota Pekanbaru, Dinas Tanaman Pangan Hortikultura dan Perkebunan Provinsi Riau dan Penyuluh Pertanian.Jumlah sampel petani ynag dijadikan responden sebanyak 24 petani bawang merah atau seluruh populasi petani bawang merah Kota Pekanbaru tahun 2017. Disamping itu, diambil sampel sebanyak 3 orang penyuluh lapangan dan responden expert bawang merah sebanyak 3 responden.

\section{Metode Analisis Data}

Dalam penelitian ini, teknik analisis data menggunakan analisis AWOT yaitu kombinasi antara SWOT (Strengths, Weaknesses, Opportunities and Threats) dengan analisis AHP (Analytic Hierarchy Process). Analisis A"WOT ini dilaksanakan dengan tiga tahapan : (1) Pengumpulan Data, (2) Analisa Data, (3) 
Perumusan Strategi. Tahapan-tahapan ini dapat dijabarkan prosesnya dalamenam langkah, sehingga akhirnya didapatkan pilihan alternatifalternatif strategi. Langkah-langkah tersebut adalah sebagai berikut: (1) Identifikasi kekuatan dan kelemahan di lingkungan internal, (2) Identifikasi peluang dan ancaman di lingkungan eksternal, (3) Penyusunan matrik faktor internal, (4) Penyusunan matrik faktor eksternal, (5) Tahap analisis, (6) Tahap penyusunan strategi. Strategi-strategi yang diperoleh darianalisis SWOT selanjutnya ditentukan strategi prioritasnya menggunakan matrik perbandingan berpasangan Saaty dengan bantuan software Expert Choice 2000.

\section{HASIL DAN PEMBAHASAN}

Secara ringkas, hasil identifikasi lingkungan internal (kekuatan dan kelemahan) dan eksternal (peluang dan ancaman) diagribisnis bawang merah di Kota Pekanbaru. Hasil pemadanan informasi lingkungan internal dan eksternal ditunjukkan pada Gambar 1.

\section{Faktor Internal}

Beberapa kekuatan dan kelemahan yang terdapat dalam pengembangan agribinis bawang merah di Kota Pekanbaru

\section{A. Kekuatan}

1. Petani berpengalaman dalam berusaha tani bawang

2. Dukungan yang kuat dari pemerintah

3. Komoditi bawang merah dapat disimpan lama

4. Petani sudah pernah membuat bibit bawang merah

5. Tersedianya tenaga kerja

6. Sarana produksi mudah diperoleh kecuali bibit

7. Lokasi yang dekat dengan pasar

B. Kelemahan

1. Kualitas SDM yang terbatas

2. Sulitnya mendapatkan bibit bawang merah yang bersertifikat

3. Perencanaan dalam usaha tani yang masih lemah

4. Produktivitas bawang yang masih rendah

5. Modal usahatani yang kecil

6. Belum ada bibit bawang merah yang adaptasi dengan iklim yang di Riau
7. Kualitas bawang rendah

8. Kurang penguasaan teknologi

9. Belum adanya lembaga khusus yang menangani tentang pemasaran

\section{Faktor Eksternal}

\section{A. Peluang}

1. Permintaan pasar cukup tinggi

2. Perkembangan teknologi yang semakin maju

3. Pembatasan impor bawang merah

4. Teknologi pembenihan bawang merah dari biji

5. Harga jual cukup tinggi

6. Peluang ekspor ke negara-negara asean

B. Ancaman

1. Sebagian besar lahan usahatani bukanmilik petani

2. Serangan penyakit fusarium / moler

3. Iklim yang tidak menentu

4. Masuknya bawang illegal

5. Harga yang tidak stabil

Matrik SWOT adalah matrik yang menginteraksikan faktor strategis internal dan eksternal. Matrik ini dapat menggambarkan secara jelas bagaimana peluang dan ancaman (eksternal) yang dihadapi dapat disesuaikan dengan kekuatan dan kelemahan (internal) yang dimiliki (Freddy Rangkuti, 2003). Hasil dari interaksi faktor strategis internal dengan eksternal menghasilkan alternatif-alternatif strategi. Matrik SWOT menggambarkan berbagai alternatif strategi yang dapat dilakukan didasarkan hasil analisis SWOT. Berdasarkan matrik SWOT terbentuk empat alternatif strategi pengembangan agribisnis bawang merah di Kota Pekanbaru. Alternatif strategi tersebut adalah :

A. Strategi S-O (Strength-Opportunity), adalah strategi yang digunakan dengan memanfaatkan/mengoptimalkan kekuatan yang dimilikinya untuk memanfaatkan berbagai peluang yang ada.

1. Meningkatkan luas areal tanaman bawang merah yang bertujuan untuk memenuhi permintaan konsumen dan pasar (S1, S2, S3, S5, S6, S7, O1, O2, O3).

2. Mendorong petani untuk menjadi penangkar bibit bawang merah (S1, S3, $\mathrm{S} 4, \mathrm{O} 2)$ 
3. Menyusun Standar Operasioanal Prosedur (SOP) budidaya bawang merah (S1, P2, O2)

B. Strategi W-O (Weeknesses-Opportunity), Strategi ini diterapkan berdasarkan pemanfaatan peluang yang ada dengan cara meminimalkan kelemahan yang ada.

1. Pelatihan agribisnis bawang merah (W1, W3, W6, W7, W8, W9, O1, O2,O4).

2. Melakukan ujicoba (demplot) beberapa varietas bawang merah untuk mendapatkan varitas yang cocok dengan iklim di Riau (W1, W2, W4, W6, W7, $\mathrm{W} 8, \mathrm{O} 2, \mathrm{O} 4)$

3. Mendorong lembaga penelitian untuk menghasilkan varitas baru yang cocok dengan kondisi di Riau (W2, W4, W5, W6, W7, W8, W9, O2, O3, O4, O6)

C. Strategi S-T (Strength-Threats), adalah strategi menggunakan kekuatan tertentuyang dimiliki untuk menghadapi lingkungan yang tidak menguntungkan atau ancaman.

\begin{tabular}{|c|c|c|}
\hline Faktor Eksternal & $\begin{array}{l}\text { Kekuatan (Strenghts) } \\
\text { 1. Petani berpengalaman dalam } \\
\text { berusaha tani bawang } \\
\text { 2. Dukungan yang kuat dari } \\
\text { pemerintah } \\
\text { 3. Komoditi bawang merah dapat } \\
\text { disimpan lama } \\
\text { 4. Petani sudah pernah membuat } \\
\text { benih bawang merah } \\
\text { 5. Tersedianya tenaga kerja } \\
\text { 6. Sarana produksi mudah } \\
\text { diperoleh kecuali bibit } \\
\text { 7. Lokasi yang dekat dengan pasar }\end{array}$ & $\begin{array}{l}\text { Kelemahan (Weeknesses) } \\
\text { 1. Kualitas SDM petani yang } \\
\text { terbatas } \\
\text { 2. Sulitnya mendapatkan bibit } \\
\text { bawang merah yang bersertifikat } \\
\text { 3. Perencanaan dalam usaha tani } \\
\text { yang masih lemah } \\
\text { 4. Produktivitas bawang yang masih } \\
\text { rendah } \\
\text { 5. Modal usahatani yang kecil } \\
\text { 6. Belum ada benih bawang merah } \\
\text { yang adaptasi dengan iklim yang } \\
\text { di Riau } \\
\text { 7. Kualitas bawang rendah } \\
\text { 8. Kurang penguasaan teknologi. } \\
\text { 9. Belum adanya lembaga khusus } \\
\text { yang menangani tentang } \\
\text { pemasaran }\end{array}$ \\
\hline $\begin{array}{l}\text { Peluang (Opportunites) } \\
\text { 1. Permintaan pasar yang cukup } \\
\text { tinggi } \\
\text { Perkembangan teknologi yang } \\
\text { semakin maju } \\
\text { 2. Pembatasan impor bawang } \\
\text { merah } \\
\text { 3. Teknologi pembenihan } \\
\text { bawang merah dari biji } \\
\text { 4. Harga jual cukup tinggi } \\
\text { 5. Peluang ekspor ke negara- } \\
\text { negara asean }\end{array}$ & \begin{tabular}{|l} 
Strategi SO \\
1. Meningkatkan luas areal \\
tanaman bawang merah yang \\
bertujuan untuk memenuhi \\
permintaan konsumen dan pasar \\
(S1, S2, S3, S5, S6, S7, O1, O2, \\
O3) \\
2. Mendorong petani untuk \\
menjadi penangkar benih \\
bawang merah (S1, S3, S4, O2) \\
3. Menyusun Standar Operasioanal \\
Prosedur (SOP) budidaya \\
bawang merah (S1, P2, O2)
\end{tabular} & \begin{tabular}{|l} 
Strategi WO \\
1. Pelatihan agribisnis bawang \\
merah (W1, W3, W6, W7, W8, \\
W9, O1, O2,O4) \\
2. Melakukan ujicoba (demplot) \\
beberapa varitas bawang merah \\
untuk mendapatkan varietas \\
yang cocok dengan iklim di Riau \\
(W1, W2, W4, W6, W7, W8, O2, \\
O4) \\
3. Mendorong lembaga penelitian \\
untuk menghasilkan varietas \\
baru yang cocok dengan \\
kondisidi Riau (W2, W4, W5,
\end{tabular} \\
\hline
\end{tabular}

1. Menetapkan kawasan pengembangan agribisnis bawang merah serta pengaturan pola tanam (S1, S2, S3, S7, T1, T3, T4, T5, T7)

2. Pengujian tingkat kesuburan dan patogen tanah pada lahan yang akan digunakan (S5, S6, S7, T2, T3)

D. Strategi W-T (Weeknesses-Threats), adalah Strategi ini didasarkan pada kegiatan yang bersifat defensive dan berusaha meminimalkan kelemahan yang ada serta menghindari ancaman.

1. Meningkatkan peran karantika dan bea cukai (T4)

2. Mendorong petani untuk memamfaatkan kredit untuk modal usaha (W5) 


\begin{tabular}{|c|c|c|}
\hline & & $\begin{array}{l}\text { W6, W7, W8, W9, O2, O3, O4, } \\
\text { O6) }\end{array}$ \\
\hline $\begin{array}{l}\text { Ancaman (Threats) } \\
\text { 1. Sebagian besar lahan } \\
\text { usahatani bukan milik petani } \\
\text { 2. Serangan penyakit fusarium / } \\
\text { moler } \\
\text { 3. Iklim yang tidak menentu } \\
\text { 4. Masuknya bawang ilegal } \\
\text { 5. Harga yang tidak stabil }\end{array}$ & 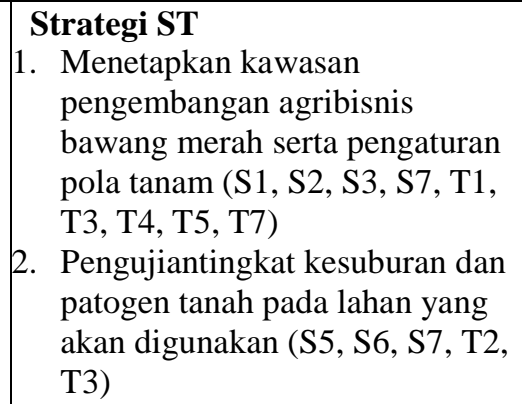 & 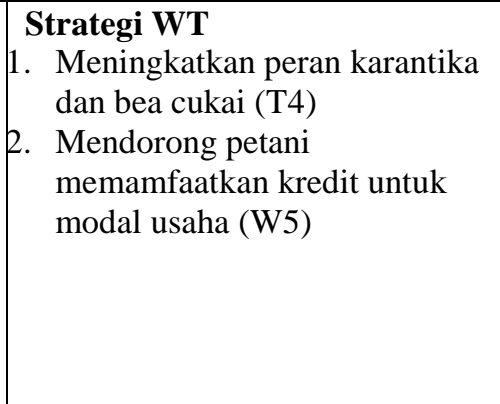 \\
\hline
\end{tabular}

Gambar 1. Matrik Analisis SWOT Pengembangan Bawang Merah di Kota Pekanbaru

Pemilihan Prioiritas Strategi Pengembangan Agribisnis Bawang Merah

Analisis pemilihan strategi prioritas dalam pengembangan agribisnis bawang merah di kota Pekanbaru dilakukan menggunakan analisis AHP dengan bantuan softwareExpert Choice 2000. Hasil analisis dengan teknik AHP dan didasarkan pada pilihan perbandingan para pakar, menggunakan prinsip perbandingan berpasangan (pairwise comparisons) didapatkan hasil prioritas alternatif strategi pengembangan agribisnis bawang merah sebagai mana ditunjukkan pada Gambar 2.

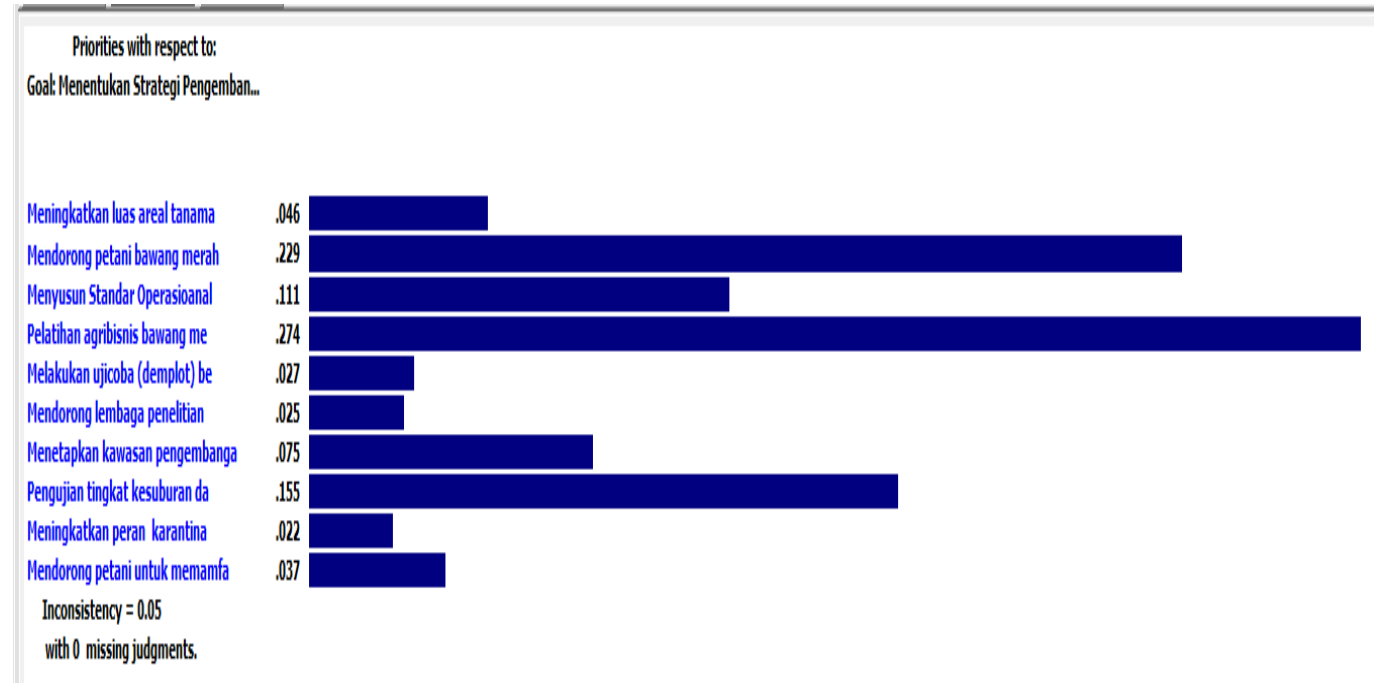

Gambar 2. Hasil Pembobotan Strategi Pengembangan Bawang Merah Dengan Expert Choice

Penentuan prioritas dilakukan untuk menentukan alternatif yang dijadikan prioritas dalam pengambilan keputusan. Indeks Konsistensi /CI yang baik adalah CI yang tidak melebihi dari $10 \%$ atau 0,10 . Hal ini menandakan bahwa responden atau pendapat yang dihasilkan adalah cukup konsisten.Hasil analisis prioritas pengembangan agribisnis bawang merah dapat dilihat pada gambar 2 dan Tabel 1. Pengolahan ini telah memenuhi persyaratan rasio inkonsistensi $\leq 0,1$, yaitu sebesar 0,05 , yang artinya hasil pengolahan strategi pengembangan bawang merah ini dapat digunakan. 
Tabel 1. Prioritas Alternatif Strategi Pengebangan Bawang Merah

\begin{tabular}{|c|c|c|c|}
\hline Alternatif Strategi & Bobot & Prioritas & Rasio Inkosisten \\
\hline Pelatihan agribisnis bawang merah & 0.274 & 1 & \multirow[t]{10}{*}{0.05} \\
\hline $\begin{array}{l}\text { Mendorong petani untuk menjadi penangkar } \\
\text { benih bawang merah }\end{array}$ & 0.229 & 2 & \\
\hline $\begin{array}{l}\text { Pengujian tingkat kesuburan dan patogen tanah } \\
\text { pada lahan yang akan digunakan }\end{array}$ & 0.155 & 3 & \\
\hline $\begin{array}{l}\text { Menyusun Standar Operasioanal Prosedur (SOP) } \\
\text { bawang merah }\end{array}$ & 0.111 & 4 & \\
\hline $\begin{array}{l}\text { Menetapkan kawasan pengembangan agribisnis } \\
\text { bawang merah serta pengaturan pola tanam }\end{array}$ & 0.075 & 5 & \\
\hline $\begin{array}{l}\text { Meningkatkan luas areal tanaman bawang merah } \\
\text { untuk memenuhi permintaan pasar }\end{array}$ & 0.046 & 6 & \\
\hline $\begin{array}{l}\text { Mendorong petani memamfaatkan kredit untuk } \\
\text { modal usaha }\end{array}$ & 0.037 & 7 & \\
\hline $\begin{array}{l}\text { Melakukan ujicoba (demplot) beberapa varitas } \\
\text { bawang merah untuk mendapatkan varitas yang } \\
\text { cocok dengan iklim di Riau }\end{array}$ & 0.027 & 8 & \\
\hline $\begin{array}{l}\text { Mendorong lembaga penelitian untuk } \\
\text { mendapatkan varitas baru yang cocok dengan } \\
\text { iklim di Riau }\end{array}$ & 0.025 & 9 & \\
\hline Meningkatkan peran karantina dan bea cukai & 0.022 & 10 & \\
\hline
\end{tabular}

Berdasarkan hasil pengolahan strategi dapat dilakukan pada pengembangan agribisnis bawang merah di Kota Pekanbaru adalah :

1. Strategi yang pertama adalah pelatihan agribisnis dengan bobot 0.274 .

Menurut Abdurrahmat Fathoni (2006) Sumber Daya Manusia merupakan modal dan kekayaan yang terpenting dari setiap kegiatan manusia. Manusia sebagai unsur terpenting mutlak dianalisis dan dikembangkan dengan cara tersebut. Waktu, tenaga dan kemampuanya benar-benar dapat dimanfaatkan secara optimal bagi kepentingan organisasi, maupun bagi kepentingan individu.Berdasarkan pengertian tersebut dapat disimpulkan bahwasumber daya manusia adalah suatu proses mendayagunakanmanusia sebagai tenaga kerja secara manusiawi, agar potensifisik dan psikis yang dimilikinya berfungsi maksimal bagi pencapaian tujuan organisasi (lembaga).

2. Strategi pengembangan agribisnis yang kedua adalah mendorong petani untuk menjadi penangkar benih bawang merah dengan bobot 0,229. Dalam rangka meningkatkan kualitas dan kuantitas produksi bawang merah, peran benih sebagai input produksi merupukan tumpuan utama untuk mencapai keberhasilan dalam usahatan bawang merah. Mengingat pentingnya peran benih maka diperlukan upaya untuk meningkatkan produksi benih bersertifikat dalam kegiatan agribisnis bawang merah. Penggunaan benih bersertifikat dapat mengurangi resiko kegagalan budidaya karena bebas dari serangan hama dan penyakit dan mampu tumbuh baik pada kondisi lahan yang kurang menguntungkan.

3. Strategi pengembangan agribisnis bawang merah yang ketiga adalah pengujian tingkat kesuburan dan patogen tanah pada lahan yang akan digunakan dengan bobot sebesar 0.155 .

Strategi ini adalah menguji tingkat kesuburan tanah serta pathogen apa saja yang ada pada lahan yang digunakan. Hasil pengujian ini akan bermafaat dalam memberkan rekomendasi pemupukan serta tindakan lainya dalam penyusunan Standar Operasional Prosedur (SOP) nantinya. Organisme tanah mempengaruhi pertumbuhan tanaman dan organisme lain yang hidup di atas tanah dan sebaliknya. Tanaman dapat mempengaruhi secara kuat 
aktivitas dan komposisi komunitas mikroorganisme rizosfir. Sebaliknya, pertumbuhan tanaman dapat dibatasi atau dipacu oleh keberadaan mikroorganisme tanah.

4. Strategi pengembangan agribisnis bawang merah yang keempat adalah menyusun Standar Operasioanal Prosedur (SOP) bawang merah dengan bobot sebesar 0.11 . Dalam meningkatkan produksi tanaman bawang merah diperlukan penerapan teknik mulai dari pra tanam, proses budidaya sampai dengan pasca panen. Salah satu cara untuk meningkatkan produksi bawang merah adalah dengan melakukan perbaikan teknik budidaya. Mencapai tingkat produksi optimal maka usaha tani bawang merah perlu menerapkanStandar Prosedur Operasional (SPO) berbasis norma budidaya bawang merah yang baik dan benar (Good Agriculture Practice) (Dinas Pertanian dan Ketahanan Pangan, 2017).

5. Strategi pengembangan agribisnis yang kelima adalah menetapkan kawasan pengembangan agribisnis bawang merah serta pengaturan pola tanam dengan bobot 0,075 . Upaya pemerintah untuk mendorong produksi dalam negeri dan meningkatkan dayasaing bawang merah dalam negeri juga diupayakan dengan disusunnya kebijakan terkait dengan budidaya bawang merah.Salah satu kebijakan pemerintah terkait dengan budidaya bawang merah adalah kebijakan pengembangan penanaman bawang merah.

6. Strategi yang keenam adalah meningkatkan luas areal tanaman bawang merah untuk memenuhi permintaan pasar dengan bobot 0,046 . Pengembangan komoditas bawang merah bertujuan untuk meningkatkan stabilitas produksi, ketersediaan/distribusi, pemanfaatan dan harga bawang merah di Indonesia.Rahotman

Sinaga,

Nurcahyaningtyas (2013) dalam penelitian Faktor-Kaktor Yang Mempengaruhi Produksi Bawang Merah : Studi Kasus di Desa Srigading,Kecamatan Sanden, Kabupaten Bantul dapat diperoleh kesimpulan bahwa luas lahan berpengaruh positif dan signifikan terhadap jumlah produksi bawang merah.
7. Strategi yang ketujuh adalah mendorong petani memamfaatkan kredit untuk modal usaha dengan bobot 0,037 .

Masalah seputar penyediaan modal dan sulitnya akses ke perbankan umum adalah kendala yang sering dilontarkan oleh para petani, baik petani tradisional, pedagang maupun pengumpul hingga industri rumah tangga yang berbasis pertanian. Kredit sektor pertanian termasuk kredit produktif yang menghasilkan barang berupa bahan makanan utama rakyat Indonesia, membicarakan kredit sektor pertanian dengan sendirinya tidak akan terlepas dari pola tata hidup pertanian yang selalu terkait dengan keadaan alam, luas tanah garapan, pola tanam, dan musim.Kredit pada sektor pertanian ini pada umumnya adalah kredit program yang merupakan kredit masal dan sering bersifat politis, kredit yang bersifat masal seringkali memberikan beban berat kepada bank BUMN khususnya bank pemerintah yang lebih dominan memberikan kredit pada sektor ini.

8. Strategi yang kedelapan adalah melakukan ujicoba (demplot) beberapa varitas bawang merah untuk mendapatkan varitas yang cocok dengan iklim di Riau dengan bobot 0,027 .

Berbagai penelitian telah dilakukan untuk menguji adaptasi varietas bawang merah salah satunya adalah uji adaptasi varietas bawang merah pada agroekosistem lahan pasang surut, rawa, dan gambut di Sumatera Selatan.Pengujian bertujuan untuk mengetahui kelayakan tumbuh dan daya hasil bawang merah pada berbagai agroekosistem tersebut. Hasil pengujian menunjukkan bahwa varietas Ampenan berdaya hasil lebih tinggi di lahan gambut, sedangkan varietas Ampenan dan Bima lebih beradaptasi di lahan sulfat masam (Koswara 2007).

9. Strategi pengembangan agribisnis yang kesembilan adalah mendorong lembaga penelitian untuk mendapatkan varitas baru yang cocok dengan iklim di Riau dengan bobot 0,025 .

Kegiatan pengembangan bawang merah yang telah dilakukan oleh pemerintah meliputi pengembangan sistem pertanian bawang merah adaptif terhadap perubahan iklim dan kondisi lingkungan, penyediaan 
dan karakterisasi sumberdaya genetik untuk pengembangan varietas adaptif terhadap perubahan iklim dan penanaman pada agroklimat lokal spesifik. Pemuliaan dan bioteknologi benih bawang merah untuk menghadapi perubahan iklim, produksi bibit bawang merah adaptif iklim lokal.

Selain itu juga dilakukan pengembangan teknologi budidaya bawang merah yang adaptif terhadap perubahan iklim global, pengembangan teknologi pengendalian hama dan penyakit terpadu biointensif bawang merah menghadapi perubahan iklim global dan pengembangan teknologi penyimpanan jangka panjang bawang merah segar pada suhu rendah untuk mengantisipasi fluktuasi produksi sebagai akibat

10.Strategi pengembangan agribisnis bawang merah yang kesembilan adalah meningkatkan peran karantina dan bea cukai dengan bobot 0,022 .

Tujuan dari karantina tumbuhan secara umum adalah mencegah masuk dan tersebarnya HPT, dari suatu daerah ke daerah lain dengan jalan undang-undang. Menurut Undang-Undang No. 16 Tahun 1992 tentang Karantina Hewan, Ikan dan Tumbuhan, karantina tumbuhan bertujuan :

a) Mencegah masuknya HPT karantina dari luar negeri ke dalam wilayah negara RI;

b) Mencegah tersebarnya HPT karantina dari suatu area ke area lain dalam wilayah negara RI; dan

c) Mencegah keluarnya HPT tertentu dari wilayah negara RI apabila negara tujuan menghendakinya.

Sedangkan tugas bea dan cukai yang berada digaris depan wilayah Indonesia sebagai pintu penjaga perbatasan atas masuk dan keluarnya barang impor dan ekspor, memiliki peran yang sangat penting bagi kelancaran arus barang yang keluar masuk wilayah Negara kesatuan republik Indonesia ini.

\section{KESIMPULAN DAN SARAN}

\section{Kesimpulan}

1. Strategi yang dapat dilakukan dalam pengembangan agribisnis bawang merah di Kota Pekanbaru adalah : 1) Pelatihan agribisnis bawang merah, 2) Mendorong petani untuk menjadi penangkar benih bawang merah, 3) Pengujian tingkat kesuburan dan patogen tanah pada lahan yang akan digunakan, 4) Menyusun Standar Operasioanal Prosedur (SOP) bawang merah, 5) Menetapkan kawasan pengembangan agribisnis bawang merah serta pengaturan pola tanam, 6) Meningkatkan luas areal tanaman bawang merah untuk memenuhi permintaan pasar, 7) Mendorong petani memamfaatkan kredit untuk modal usaha, 8) Melakukan ujicoba (demplot) beberapa varitas bawang merah untuk mendapatkan varitas yang cocok dengan iklim di Riau, 9) Mendorong lembaga penelitian untuk mendapatkan varitas baru yang cocok dengan iklim di Riau, 10) Meningkatkan peran karantina dan bea cukai.

2. Strategi pengembangan agribisnis bawang merah utama yang sesuai di Kota Pekanbaru adalah pelatihan agribisnis bawang merah dengan bobot sebesar 0.274 .

\section{Saran}

Pelatihan agribisnis bawang merah di Kota Pekanbaru, sebaiknya dinas terkait dapat berdiskusi dengan petani tentang kebutuhan materi pelatihan yang mereka perlukan sesuai kondisi petani.

\section{DAFTAR PUSTAKA}

Abdurrahmat $\quad 2006$. ManajemenSumber daya Manusia. Rineka Cipta, Jakarta.

Kementrian Pertanian. 2014. Statistik Ekspor Impor Komoditi Pertanian, 2001-2013. Direktorat Jenderal PengolahandanPemasaranHasilPertanian, Kementrian Pertanian. http://www.pertanian.go.id/ap_pages/mo d/datahorti.

Kementrian Pertanian. 2015. Produksi Bawang Merah Menurut Provinsi 2010-2014, Kementrian Pertanian.

Dinas Pertanian dan Ketahanan PanganPamekasan. 2017. Standar Prosedur Operasional (SPO) Budidaya Bawang Merah.Dinas Pertanian dan Ketahanan Pangan.Pamekasan 
Koswara, E. 2007.Teknik pengujian daya hasil beberapa varietas bawang merah di lahan pasang surut Sumatera Selatan. Buletin Teknik Pertanian 12(1): 1-3

Marimin. 2008. Teknik dan Aplikasi Pengambilan Keputusan Kriteria Majemuk. Jakarta : PT. Gramedia Widiasarana Indonesia.

Rangkuti, Freddy. 2003. Analisis SWOT Teknik Membelah Kasus Bisnis. PT. Gramedia Pustaka Utama. Jakarta.

Rahotman Sinaga, Nurcahyaningtyas, 2013.Faktor-Kaktor Yang Mempengaruhi Produksi Bawang Merah : Studi Kasus di Desa Srigading, Kecamatan Sanden, Kabupaten Bantul, Universitas Atmajaya Yogyakarta

Soekartawi. 2002. Analisis Usahatani. Jakarta: Universitas Indonesia.

Soekartawi. 2003. Teori Ekonomi Produksi (Dengan Pokok Bahasan AnalisisFungsi Cobb-Douglas). PT. Raja Grafindo Persada. Jakarta.

Saaty TL. 1980. The Analytical Hierarchy Process: Planning, Priority Setting, Resource Allocation. McGraw-Hill: New York.

Saaty TL and Niemira MP. 2006. A Framework for Making a Better Decision: How to Make More Effective Site Selection, Store Closing and Other Real Estate Decisions. Research Review. 13:1-4.

Nur R. Khoiriyah, Aminah H.M. Ariyani, dan Elys Fauziyah. 2012. Strategi Pengembangan Agroindustri Kerupuk Terasi (Studi Kasus Di Desa Plosobuden, Deket, Lamongan). Agriekonomika 1(2): 135-1. 
